\title{
Determination of optimal liquid medium for enzyme expression by Helicobacter pylori
}

\author{
Y L Lin, N Lee, E C Chan
}

\begin{abstract}
Aims-To determine the best medium for the growth and enzyme expression of Helicobacter pylori.

Methods-Twelve $H$ pylori isolates from histologically confirmed infected patients were cultured on Brucella broth (BB), Brucella broth minus bisulphite (BLBB), and brain-heart infusion broth (BHIB), all supplemented with $5 \%(v / v)$ fetal calf serum. Growth rates and enzyme expressions of all $H$ pylori isolates cultivated in these media were evaluated.

Results-Although both BLBB and BHIB supported good growth of $H$ pylori under microaerophilic conditions, the total protein content of $H$ pylori detected was much higher with BHIB cultivation. Measurement of the specific activities of urease, phospholipase $\mathrm{C}$, and sphingomyelinase for $12 \mathrm{H}$ pylori isolates cultivated in these media, showed that BHIB supported the highest expression of these enzymes. Although BLBB supported better growth of $H$ pylori than $B B$, it did not increase enzyme expression.

Conclusions-Cultivation of $H$ pylori in BHIB is recommended for studies on the physiology, metabolism, and enzyme expression of the organism.

( 7 Clin Pathol 1996;49:818-820)
\end{abstract}

Keywords: enzyme expression, culture medium, sphingomyelinase, Helicobacter pylori.

Helicobacter pylori is now accepted as an important aetiological agent in the development of antral gastritis, and is strongly associated with gastritis, peptic ulcer, and gastric cancer. ${ }^{1-3}$ Culture of $H$ pylori is needed for strain classification, typing, antibiotic resistance monitoring, and other research. Several liquid media have been reported to support good growth of $H$ pylori, ${ }^{4-6}$ such as Brucella broth (BB) and brain-heart infusion broth (BHIB) with fetal calf serum supplement, and these are now used routinely in laboratories. A previous study ${ }^{7}$ showed that BB, BLBB (Brucella broth without bisulphite), and BHIB were used to facilitate culture of $H$ pylori for metabolism and enzyme studies. We have detected various degrees of enzyme expression of $H$ pylori when the organism was cultured in different liquid media with fetal calf serum supplement, so we suspected that the components of different media might affect enzyme expression. The purpose of this study was, therefore, to evaluate which of the routine culture media supported the highest and most consistent expression of enzymes by $H$ pylori.

\section{Methods}

MEDIA AND CHEMICALS

Both BB and BHIB were purchased from Difco (Detroit, Michigan, USA). Chocolate agar base was from Oxoid (Hampshire, UK). Fetal calf serum (FCS) was purchased from Gibco (Grand Island, New York). All other supplements were obtained from Sigma (St Louis, Missouri, USA). Chocolate agar plates, $\mathrm{BB}$, and $\mathrm{BHIB}$ were prepared according to the manufacturer's instructions. BLBB was prepared by mixing $10 \mathrm{~g}$ tryptone, $10 \mathrm{~g}$ peptamine, $1 \mathrm{~g}$ glucose, $2 \mathrm{~g}$ yeast extract, and $5 \mathrm{~g}$ sodium chloride in 1 litre of deionised water. Fetal calf serum (final concentration 5\% $\mathrm{v} / \mathrm{v}$ ) was added to all media.

BACTERIAL STRAINS AND CULTIVATION

Twelve clinical isolates of $H$ pylori, $7 \mathrm{~K}, 8 \mathrm{~K}$, $34 \mathrm{~K}, 85 \mathrm{~K}, 86 \mathrm{~K}, 89 \mathrm{~K}, 93 \mathrm{~K}, 34,36,37,41$, and 46, obtained from Dr N Lee of Chang Gung Memorial Hospital, Taiwan, were investigated. Strain $8 \mathrm{~K}$ was isolated from a patient with a well developed duodenal ulcer, and the remaining strains were isolated from patients with moderate symptoms. Stock cultures were stored in BB with $10 \%$ FCS and glycerol at $-70^{\circ} \mathrm{C}$.

$H$ pylori cultures grown on chocolate agar (supplemented with 5\% FCS) for three days were used as inocula, and one loopful of cells was suspended in a $150 \mathrm{ml}$ flask containing $50 \mathrm{ml} \mathrm{BB}, \mathrm{BLBB}$, or BHIB. The inoculum was grown for 24 hours, and $3 \mathrm{ml}$ was inoculated into a $150 \mathrm{ml}$ flask containing $50 \mathrm{ml}$ of each medium to provide an initial optical density $\left(\mathrm{OD}_{625}\right)$ of 0.05 . Flasks with loose caps were incubated at $37^{\circ} \mathrm{C}$ in anaerobic jars containing CampyPaks and shaken (110 rpm). Cell growth was monitored daily for up to five days by measuring the $O D$ at $625 \mathrm{~nm}$.

PREPARATION OF $H$ PYLORI LYSATE

After cultivation for five days $H$ pylori cells collected from $10 \mathrm{ml}$ medium were washed and resuspended in $1 \mathrm{ml}$ of $0.05 \mathrm{M}$ phosphate buffered saline (PBS, pH 7.2); the suspension was disrupted by sonication (Heat-System Model XL 200, New York) in an ice bath at $35 \%$ pulse with 30 second intervals for three minutes. After the cells were separated by centrifugation at $12000 \times g$ for 20 minutes at $4^{\circ} \mathrm{C}$, the supernatant fraction was used as lysate for enzyme assay. Protein concentration was determined by the Bradford method as described in the Bio-Rad protein assay kit instruction manual. 
ENZYME ASSAY

The sphingomyelinase activity of $H$ pylori cells was determined by measuring the rate of the substrate analog, $\mathrm{N}$ - $\omega$-trinitrophenylaminolauryl-sphingomyelin hydrolysis, as described before..$^{8}$ The reaction product, trinitrophenylaminolauryl-sphingosine (TNPAL-sphingosine) was measured spectrophotometrically at $330 \mathrm{~nm}$. The unit of activity was the amount of enzyme producing $1 \mu \mathrm{mol}$ of trinitrophenylamino residue per hour at $37^{\circ} \mathrm{C}$.

Urease activity was assayed using a substrate (urea) solution containing the indicator bromocresol purple. ${ }^{10}$ Bromocresol purple provided a clear, vivid, and linear colour change. The substrate solution for use in the urease assay was made up as follows: $8 \mathrm{mg}$ bromocresol purple (BCP) powder (Sigma) was dissolved in $1.48 \mathrm{ml} 0.01 \mathrm{M} \mathrm{NaOH}$ and the volume made to $100 \mathrm{ml}$ with deionised water. After the addition of $100 \mathrm{mg}$ urea, EDTA was added to a final concentration of $0.2 \mathrm{mM}$ to chelate any heavy metal ions which might inhibit the urease, and to provide buffering. The $\mathrm{pH}$ of the substrate was adjusted to 5.1 using $0.1 \mathrm{M} \mathrm{NaOH}$ or $0.1 \mathrm{M} \mathrm{HCl}$, and the solution stored at $4^{\circ} \mathrm{C}$ until used. $H$ pylori lysates of the appropriate dilution $(2 \mu \mathrm{l})$ were added to cuvettes containing $1 \mathrm{ml}$ of substrate solution. Absorbance at $588 \mathrm{~nm}$ was read every 20 seconds using a DU70 spectrophotometer (Beckman Instrument). Reactions were carried out at room temperature, and the rates were calculated from linear portions of the curves (between 0 and 20 minutes). One unit of urease activity was defined as that amount capable of increasing one absorbance unit of reaction solution per minute.

The phospholipase $\mathrm{C}$ activity was assayed by measuring the rate of p-nitrophenyl phosphorylcholin (PNP-PC) hydrolysis by $H$ pylori lysate. ${ }^{11}$ The reaction mixture containing 20 mM PNP-PC and $20 \mu \mathrm{l} H$ pylori lysate in PBS buffer $\left(\mathrm{pH} \mathrm{7.2)}\right.$ was incubated at $37^{\circ} \mathrm{C}$ for one hour. The unit of activity was the amount of enzyme producing $1 \mathrm{nmol}$ of $\mathrm{p}$-nitrophenol (PNP) per hour. Specific activity of the enzyme was given as units of enzyme activity per milligram of protein.

\section{Results and discussion}

When $H$ pylori $8 \mathrm{~K}$ was grown in different liquid media supplemented with fetal calf serum under microaerophilic conditions, BHIB or BLBB supported a stronger growth than $\mathrm{BB}$ (fig 1). The results for strain $8 \mathrm{~K}$ are representative of those obtained with an additional 11 strains of $H$ pylori. These results also confirm the earlier report that $\mathrm{BB}$ is not ideal for growth of $H$ pylori because of its bisulphite inhibitory effect. ${ }^{7}$ Although BHIB and BLBB supported growth of all the strains tested to the same extent, $H$ pylori cultured in BHIB had a much higher protein content (table 1). Therefore, the investigation of enzyme expression of this bacterium cultured in different media may be useful in clinical research laboratories that require harvests of large quantities of $H$ pylori enzymes. The pathogenic mechanisms underlying $H$ pylori
Table 1 Protein content of 12 Helicobacter pylori isolates cultivated in different liquid media

\begin{tabular}{llll}
\hline \multirow{2}{*}{ Isolates } & \multicolumn{3}{l}{ Protein content $(\mathrm{mg} / \mathrm{g}$ cell wet weight) } \\
\cline { 2 - 4 } & $B B$ & $B L B B$ & $B H I B$ \\
\hline $7 \mathrm{~K}$ & 6.02 & 7.57 & 10.72 \\
$8 \mathrm{~K}$ & 6.65 & 6.98 & 11.43 \\
$34 \mathrm{~K}$ & 5.98 & 5.67 & 11.45 \\
$85 \mathrm{~K}$ & 7.33 & 7.11 & 14.32 \\
$86 \mathrm{~K}$ & 6.65 & 6.12 & 10.21 \\
$89 \mathrm{~K}$ & 5.56 & 5.54 & 11.22 \\
$93 \mathrm{~K}$ & 5.78 & 6.76 & 12.12 \\
34 & 6.51 & 6.11 & 11.31 \\
36 & 5.99 & 6.32 & 12.87 \\
67 & 6.64 & 5.47 & 11.98 \\
41 & 5.68 & 5.99 & 11.33 \\
46 & 6.43 & 6.01 & \\
\hline
\end{tabular}

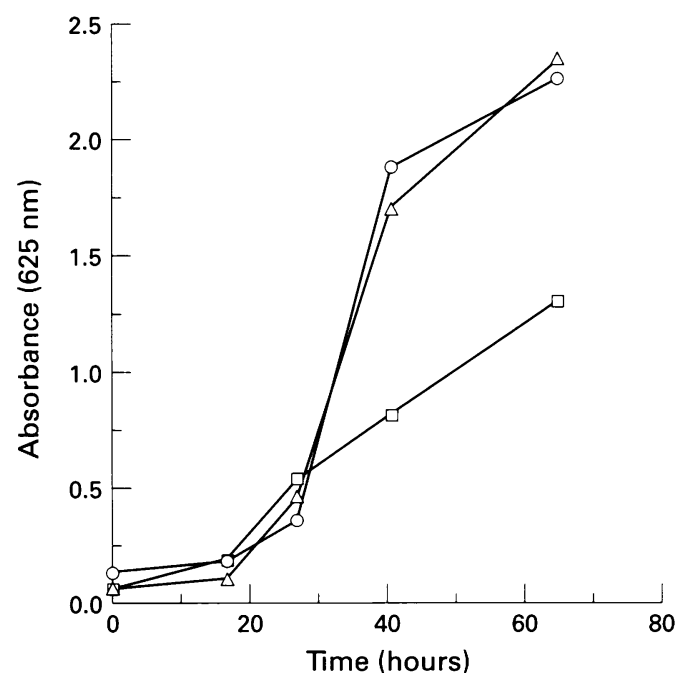

Figure 1 Growth of $\mathrm{H}$ pylori $8 K$ in $B B(\square), B L B B(\triangle)$, and $\mathrm{BHIB}(\mathrm{O})$

enzymes on the gastroduodenal mucosa are not fully understood, but gastric disease associated with urease, catalase, lipase, phospholipase, protease, as well as the putative cytotoxin, have been postulated. ${ }^{12}$

In this study $H$ pylori isolates were cultured in BLBB, BB, and BHIB, respectively, and the crude cell lysates were then extracted for enzyme assays. The specific activities of three representative enzymes, sphingomyelinase, phospholipase $\mathrm{C}$, and urease, were examined. Interestingly, when we cultured $H$ pylori $8 \mathrm{~K}$, which was isolated from a patient with a severe duodenal ulcer, in BHIB, we were able to demonstrate the presence of sphingomyelinase. Sphingomyelinase is present in several pathogenic micro-organisms, ${ }^{13}$ but until now has not been identified in $H$ pylori. BHIB seems to be an optimal medium for the expression of sphingomyelinase by all the strains tested (table 2). Sphingomyelinase activity from $H$ pylori isolates from patients with moderate symptoms was not detectable when cultured either in BLBB or BB. Phospholipase C and urease activities, from all strains tested, were much higher in BHIB (table 2).

This study indicates that the degree of enzyme expression in $H$ pylori is influenced by different culture media. On the basis of data obtained in this study, it can be concluded that although both BLBB and BHIB support good growth of $H$ pylori to the same extent, the 
Table 2 Specific activities of enzyme expression by 12 Helicobacter pylori isolates cultivated in different liquid media

\begin{tabular}{|c|c|c|c|c|c|c|c|c|c|}
\hline \multirow[t]{2}{*}{ Isolates } & \multicolumn{3}{|c|}{ Sphingomyelinase ${ }^{\star}$} & \multicolumn{3}{|c|}{ Phospholipase Ct } & \multicolumn{2}{|c|}{ Urease $\ddagger$} & \multirow[b]{2}{*}{$B H I B$} \\
\hline & $B B$ & $B L B B$ & $B H I B$ & $B B$ & $B L B B$ & $B H I B$ & $B B$ & $B L B B$ & \\
\hline $7 \mathrm{~K}$ & 0.8 & 0.7 & 2.1 & 3.2 & 3.8 & 10.3 & 3.3 & 3.7 & 12.5 \\
\hline $8 \mathrm{~K}$ & 3.6 & 3.5 & 9.2 & 10.2 & 11.2 & 36.4 & 4.0 & 3.2 & 14.3 \\
\hline $34 \mathrm{~K}$ & 0.4 & 0.4 & 1.7 & 4.7 & 4.6 & 22.1 & 3.7 & 3.4 & 11.6 \\
\hline $85 \mathrm{~K}$ & 0.4 & 0.4 & 1.7 & ND & ND & 3.0 & 3.6 & 4.1 & 14.2 \\
\hline $86 \mathrm{~K}$ & $\mathrm{ND}^{\star}$ & 0.3 & 1.8 & ND & ND & 4.1 & 3.3 & 3.3 & 12.8 \\
\hline $89 \mathrm{~K}$ & ND & ND & 1.2 & 11.6 & 12.9 & 36.2 & 3.6 & 3.1 & 12.4 \\
\hline $93 \mathrm{~K}$ & 0.5 & 0.5 & 1.8 & 4.2 & 5.1 & 16.9 & 5.5 & 4.5 & 15.2 \\
\hline 34 & ND & 0.3 & 1.7 & 4.4 & 5.1 & 19.5 & 4.4 & 4.3 & 11.7 \\
\hline 36 & ND & ND & 1.4 & 18.4 & 20.6 & 49.8 & 5.0 & 3.6 & 14.4 \\
\hline 37 & ND & ND & 1.5 & 6.8 & 7.2 & 27.8 & 3.9 & 5.1 & 14.9 \\
\hline 41 & 0.6 & 0.6 & 1.7 & ND & ND & 8.7 & 4.6 & 5.6 & 14.9 \\
\hline 46 & 0.5 & 0.4 & 1.7 & 32.8 & 34.4 & 85.3 & 3.5 & 4.4 & 13.2 \\
\hline
\end{tabular}

*The specific activity is TPNAL-sphingosine $\mu \mathrm{moles} / \mathrm{hour} / \mathrm{mg}$ protein.

tThe specific activity is PNP nmoles/hour/mg protein.

$\ddagger$ The specific activity is $\mathrm{OD}_{588}$ unit/minute/mg protein.

$\mathrm{ND}=$ non-detectable

degree of enzyme expression is much higher when cultured in BHIB.

This work was supported by a grant NSC $85-2331-B-182-072$ from the National Science Council of the Republic of China.

1 Anderson LP, Holck S, Poulsen CC, Elsborg L, Justensen T and duodenal infection caused by C. pyloridis histopathological and microbiologic findings. Scand $\mathcal{F}$ Gastroenterol 1987;22:219-24.

2 Buck GE, Gourely EG, Lee WK, Subramanyam K, Latimer LM, Dinuzzo AR. Relation of Campylobacter pyloridis to gastritis and peptic ulcer. $\mathcal{F}$ Infect Dis 1986;153:664-9.

3 Forman D, Webb P, Newell D, Coleman M, Palli D, Moller H, et al. An international association between Helicobacter pylori infection and gastric cancer. Lancet 1993;341:1359-62.

4 Buck GE, Smith JS. Medium supplementation for growth of Campylobacter pyloridis. F Clin Microbiol 1987;25:597-9. Campylobacter pyloridis. F Clin Microbiol 1987;25:597-9.
Morgan DR, Freedman R, Depew CE, Kraft WG. Growth of Campylobacter pylori in liquid media. $\mathcal{f}$ Clin Microbiol 1987;25:2123-5.

6 Shahamat M, Mai UEH, Paszko-Kolva C, Yamamoto H, Colwell RP. Evaluation of liquid media for growth of Helicobacter pylori. $\mathcal{F}$ Clin Microbiol 1991;29:2835-7.
7 Hawrylik SJ, Wasilko DJ, Haskell SL, Gootz TD, Lee SE. Bisulfite or sulfite inhibits growth of Helicobacter pylori. $\mathcal{F}$ Clin Microbiol 1994;32:790-2.

8 Gatt $S$, Dinur T, Barenholz Y. A spectrophotometric method for determination of sphingomyelinase. Biochim Biophys Acta 1978;530:503-7.

9 Gillmore MS, Cruz-Rodz AL, Leimeister-Wachter M, Kreft J, Goebel W. A Bacillus cereus cytolytic determinant, cereolysin $\mathrm{AB}$, which comprises the phospholipase $\mathrm{C}$ and sphingomyelinase genes: nucleotide sequence and genetic linkage. F Bacteriol 1989;171:744-53.

10 Chandler HM, Cox JC, Healey K, MacGregor A, Premier RR, Hurrell JGR. An investigation of the use of urease-antibody conjugates in enzyme immunoassays. $\mathcal{F}$ 응 Immunol Methods 1982;53:187-94.

11 Kurioka S, Matsuda M. Phospholipase $C$ assay using p-nitrophenylphosphorylcholine together with sorbitol and its application to studying the metal and detergent requirement of the enzyme. Anal Biochem 1976;75:281-9.

12 Hazell SL, Mendz GL. The metabolism and enzymes of Helicobacter pylori: function and potential virulence effects. In: Goodwin CS, Worsley BW, eds. Helicobacter pylori: biology and clinical practice. Florida: CRC Press, 1993:115-41.

13 IIkezanla H, Mori M, Ohyabu T, Taguchi R. Studies on sphingomyelinase of Bacillus cereus. Biochim Biophys Acta 1978;528:247-56. 高

$\infty$

\author{
○
}

